Sherwood, Peter. "Sándor, Klára. 2014. A székely írás nyomában ('On the Tracks of the Székely Script'). Budapest: Typotext. 353 pp." Hungarian Cultural Studies. e-Journal of the American Hungarian Educators Association,

Volume 8 (2015): http://ahea.pitt.edu DOI: 10.5195/ahea.2015.203

\title{
Sándor, Klára. 2014. A székely írás nyomában ('On the Tracks of the Székely Script'). Budapest: Typotext. 353 pp.
}

\section{Reviewed by Peter Sherwood, László Birinyi, Sr., Distinguished Professor of Hungarian Language and Culture (Emeritus), University of North Carolina at Chapel Hill}

The few undisputed facts about the Székelys (Szeklers/Széklers/Sekels in German and sometimes also in English, Secui in Romanian, and Siculi in Latin) are soon told. This Hungarian-speaking subgroup of the Hungarians, with its own history and a somewhat distinct ethnic identity, today numbers some 500,000 to 600,000 people concentrated on the western side of the Carpathian Mountains in Romanian Transylvania, mostly in the counties of Hargita/Harghita, Kovászna/Covasna, and central and eastern Maros/Mureș. Just a few centuries ago they were more widespread in what is present-day Hungary, whereas the Bukovina Székelys, now living in Vojvodina and in southern Hungary, have their own separate history. The Székelys' origins, despite being an enduring source of fascination and controversy, remain shrouded in obscurity, and a balanced discussion of these origins is almost impossible to come by in any language.

In the present scholarly yet eminently readable and notably even-handed introduction to the intriguing Székely runiform script, Turkologist and sociolinguist Klára Sándor of Szeged University follows the principles established in her previous study, Nyelvrokonság és hunhagyomány. Rénszarvas vagy csodaszarvas? Nyelvtörténet és müvelödéstörténet [Linguistic Kinship and the Hun Tradition - Reindeer or Miracle Stag? The History of Language and the History of Culture] (Budapest: Typotext, 2011; see my 2012 review of this work at: http://ahea.pitt.edu/ojs/index.php/ahea/article/view/101). In both these works Sándor sets the debate in its vast but essential archaeological, mythological, historical, social, cultural and linguistic contexts and thus achieves more than her title suggests. This book is, in fact, a rare and reliable reference point for anyone with a serious interest in the origins of the Székely culture. If at the end of this voyage the answers are not as straightforward as some readers might have hoped at the outset, at the very least such readers will have a much clearer idea of the questions.

It is worth warning those who have only vague ideas about the Székely culture, or those who have seen only the appropriation of the allegedly "Old Hungarian Script" by dubious authorities on, say, the Internet or by local councils on town signs, that even established linguists and literature scholars have offered, and continue to offer, inaccurate opinions or speculations on this topic. Some assert, all too blithely, that the runiform script is the "original script of the Hungarians," while others claim that the script is an invention from the period of Humanism. Crude conjectures and formulations like these are misguided and misleading, so that in the book's early parts Sándor has much ground-clearing to do. She first explains why she has chosen "Székely Script" for her title and that the topic is important because the only indisputable primary examples of these texts come from the Székely region and, since they are written in Hungarian, they form a vital part of the Hungarian heritage; therefore she castigates those

$($ (c) $)$ EY

ULIS D-Serk
New articles in this journal are licensed under a Creative Commons Attribution 4.0 International License.

This journal is published by the University Library System of the University of Pittsburgh as part of its D-Scribe Digital Publishing Program and is cosponsored by the University of Pittsburgh Press 
Sherwood, Peter. "Sándor, Klára. 2014. A székely írás nyomában ('On the Tracks of the Székely Script'). Budapest: Typotext. 353 pp." Hungarian Cultural Studies. e-Journal of the American Hungarian Educators Association, Volume 8 (2015): http://ahea.pitt.edu DOI: 10.5195/ahea.2015.203

historical linguists who have unthinkingly excluded these texts from the sparse canon of early Hungarian linguistic documents.

A further chapter (it is unfortunate in such a scholarly work that the chapters and their subsections are unnumbered) is devoted to a wide-ranging history of scripts as a prelude to a thorough and -- despite the author's best efforts -- probably challenging discussion for the layman of the script she terms eastern Turkic, which is sometimes also called the Old Turkic or Orkhon script (68). This elucidation enables her to express the now generally held view that the "eastern Turkic and the Székely scripts are related, but indirectly," likely via "a chain of scripts" as yet largely undeciphered, which have "recently come to light in those parts of eastern Europe once inhabited by western Turkic groups," that have long since disappeared (75). These early Turkic peoples should, of course, be carefully distinguished from the more familiar Ottoman Turks, who appeared on the stage of history only many centuries later.

There follows a detailed discussion of an inscription from Alsóbü (north of today's Kaposvár) that is fairly reliably dated to the early tenth century. The importance of this very short text is that each of its elements appears to have a Székely runiform counterpart, which means that this inscription may well be the first recorded piece of runiform writing in the Hungarian-speaking area and perhaps the precursor of the Székely script, or even the first example of a script of this kind (143). Although various readings have been proposed, the meaning of this inscription has not been established beyond doubt, but it is possible that Transylvanian folk worked as iron smelters where the fragment bearing the inscription was found.

Following the discussion of this ancient text, the author introduces us to the historic Székely alphabet itself, carefully peeling back its several layers with the help of the history of the Hungarian language and of other relevant scripts. She establishes that this alphabet consisted of thirty-four graphemes, of which thirty-two represented phonemes and two, with two and three variants, respectively, are particularly interesting distinctive symbols for the sound-clusters (as opposed to ligatures) of $|n t|$ and $|m b|$, thus suggesting a link with Sogdian, a culturally important Middle Iranian language. This analysis shows that the Székely alphabet was a more or less transparently phonemic script reflecting assimilations not found in contemporary Hungarian spelling (that has, e.g., láttya [s/he sees] rather than látja, for example). One of the many points in this fascinating account is that, unlike in western-type alphabets, when sounded in isolation, most Székely consonants were pronounced with a preceding $|e|$; for example: $|e v|$ rather than (European) $|v i:|$ for the sign $|v|$, probably because vowels, especially $|e|$, were originally not indicated in the script. What is more, the majority of the texts were written from right to left, as in a number of oriental languages.

The next chapter is a masterly summary, alone worth the price of the book, of the numerous theories about the Székelys' origins, which, as already stated, is a highly controversial and complex issue yet one that cannot be shirked in view of a major goal of the book, namely to shed light on the questions of how and where the Székelys might have acquired their distinctive runiform script. The author concludes that at present there is no trace in Transylvania of any literate culture that could have been the precursor of this script, thus adding a further layer to the mystery of the script.

Next comes a succinct chronological survey of what Sándor calls the graffiti, that is, the brief inscriptions so far found mainly in and around churches in the Székely region, the earliest of which date from the thirteenth and fourteenth centuries. The story of each of these 
Sherwood, Peter. "Sándor, Klára. 2014. A székely írás nyomában ('On the Tracks of the Székely Script'). Budapest: Typotext. 353 pp." Hungarian Cultural Studies. e-Journal of the American Hungarian Educators Association, Volume 8 (2015): http://ahea.pitt.edu DOI: 10.5195/ahea.2015.203

monuments, nearly all of which the author has visited in person, reads like a miniature detective story, and her enthusiasm in presenting them is palpable and infectious. There follows an account of some longer texts, such as a runiform Székely calendar and the Nikolsburg (today's Mikulov in Moravia) alphabet, found in various books and codices, and this account is also often laced with exciting background stories. As we come closer to contemporary times, the author looks at what are certainly secondary accounts and uses of the script by churchmen, nobles and others. It now becomes clear that so far there is no evidence that the runiform script as we know it today was ever used for normal, everyday communication (257) or for the writing of any work of literature. In many ways, this realization only further deepens the mystery surrounding the script, as now the question becomes not just where the script came from (and when and how it did so), but also why it is found in Transylvania at all. The book concludes with an outline history of the study of the script that emphasizes how its story has become increasingly intertwined with the cultural history of the Hungarians as a whole.

Anyone wishing to challenge the thought-provoking ideas and carefully weighed considerations in this work, the first extensive study of the topic for over a century and the result (as the author explains in a winningly personal introduction) of more than twenty years of research, should note that the book's thirty-two page long bibliography of hundreds of items includes original works in Turkish, Russian and Danish as well as the more usual Western languages, in addition, of course, to Hungarian. Such a challenger will also need to be at least as well versed as the author in the half-a-dozen fields of scholarship listed earlier in this review. Therefore this study will for the foreseeable future surely remain the standard introduction to the Székely runiform script.

At present we eagerly await the other, complementary books from the author that she thinks are required; most urgently, as a prerequisite to any serious progress on the study of the script's origins and ancestry, the publication of an exhaustive catalogue raisonné of every extant example of the script. While the graphics, i.e., the runiform letters and inscriptions reproduced in this study, are on the whole admirably clear, the reduced size and quality of some of the other drawings and documents means that they are more indicative than useful. Hopefully, something similar to a catalogue will also be provided for the ancient western Turkic corpus mentioned in this work (314). More broadly, as the script forms an essential part of the Hungarian cultural heritage, Klára Sándor reiterates that she is also keen to provide a detailed account of the script's sociolinguistics, including its uses, abuses and forgeries, all down to our own times.

It is perhaps frustrating that all we can say at the moment is that more research as well as a great deal of serendipity is needed for making progress in the understanding of the Székely runiform script and its origins so judiciously and enjoyably presented here. Meanwhile, like Klára Sándor's previous book, this one, too, or at least its crucial elements, should be made available in English, even if for such a translation some additional background will no doubt be essential. 